UDK 528.389

\title{
IŠMATUOTŲ LIETUVOS PAJŪRIO ŽEMĖS PAVIRŠIAUS JUDESIŲ IR TERITORIJOS GEOLOGINIŲ RODIKLIŲ SĄSAJOS
}

\author{
Algimantas Zakarevičius, Rūta Puzienė \\ Geodezijos ir kadastro katedra, Vilniaus Gedimino technikos universitetas, \\ Sauletekio al. 11, LT-10223 Vilnius-40, Lietuva, el. paštas: gkk@ap.vtu.lt
}

Iteikta 20050629 , priimta 20050707

\begin{abstract}
Santrauka. Teritorijose, kurių stora nuosėdinė danga, matavimais nustatytos vertikaliuju Žemės paviršiaus judesių reikšmės yra tektoninių judesių ir nuosėdinès dangos sluoksnių deformacijų reikšmių suma. Tiesiogiai pagal geodeziniais matavimais gautus rezultatus sudètinga spręsti apie dabartini tokių teritorijų tektoninį aktyvumą. Kadangi ịvairių nuosėdinès dangos sluoksnių formavimasis tiesiogiai susijęs su praeityje vykusiais tektoniniais Žemès plutos judesiais, ir kiekvienas nuosédinès dangos sluoksnis teikia tam tikros informacijos apie vykusius tektoninius procesus, šią informaciją būtina panaudoti interpretuojant geodezinių matavimų duomenis.

Tyrimais, taikant koreliacinę, kompleksinę koreliacinę bei rodiklių informatyvumo analizę, nustatytos sąsajos tarp geometrinio niveliavimo būdu išmatuotų Žemès paviršiaus judesių ir nuosėdinès dangos ypatumų, ištirta skirtingų geologinių rodiklių grupių informatyvumas.
\end{abstract}

Raktažodžiai: vertikalieji Žemès plutos judesiai, teritorijos geologinė sandara, kompleksinė koreliacinè analizė, rodiklių informatyvumas, koreliacinè analizè.

\section{Ivadas}

Dabartiniai Žemės plutos judesiai yra nenutrūkstamai vykstančio geologinio proceso pasekmè, o geodeziniais metodais išmatavus gautos jų reikšmès yra sudetingos geologinès sistemos nulemti dabartiniai būvio parametrai. Tose teritorijose, kur nèra nuosèdinès dangos ir geodezinius ženklus galima irengti kristalinio pamato uolienose, geodeziniais matavimais sistemos būvio parametrai nustatomi tiesiogiai, ir šių matavimu geodezinis interpretavimas didesnių sunkumų nekelia. Tačiau tose teritorijose, kur susiformavusi nuosèdinè danga, matavimais nustatytų Žemès paviršiaus judesių reikšmès yra tektoninių judesių ir nuosėdinès dangos sluoksnių deformacijų reikšmių suma. Todèl tiesiogiai pagal geodezinius matavimus spręsti apie dabartinị tokių teritorijų tektonini aktyvumą sudėtinga. Turint omenyje, kad skirtingų nuosėdinès dangos sluoksnių formavimasis tiesiogiai susijęs su praeityje vykusiais tektoniniais Žemès plutos judesiais, ir kiekvienas nuoseddinès dangos sluoksnis teikia tam tikros informacijos apie vykusius tektoninius procesus, šią informaciją reikia panaudoti interpretuojant geodezinių matavimų duomenis [1-3].

Lietuvos teritorija yra regione, kurio nuosèdinè žemès danga stora. Storiausia ji vakarinejje Lietuvos dalyje pajūrio zonoje [1], todèl ši teritorija ir pasirinkta detaliems tyrimams.

Tyrimų tikslas - nustatyti ryšius tarp geometrinio niveliavimo būdu išmatuotų Žemès paviršiaus judesių ir nuosėdinès dangos ypatumu, ištirti skirtingu geologinių rodiklių grupių informatyvumą.

\section{Tyrimu metodika}

Sąsajoms tarp Žemès paviršiaus judesių rodiklių, gautų atlikus matavimus, ir teritorijos geologinių rodiklių (reikšmiu) nustatyti taikoma koreliacinè analizè.

Visų rodiklių tarpusavio matematinès statistinès sąveikos apibūdinamos koreliacijos koeficientų matrica

$$
R=[r]=\frac{1}{n-1} Q^{T} Q
$$

čia $Q$ - centruota (turinti nuliui lygų rodiklių vidurki) ir standartizuota (turinti vienetui lygias rodiklių dispersijas) pradinių duomenų matrica, $T$ - matricos transponavimo simbolis, $n$ - matavimų (kartotinai niveliuotų reperiu) skaičius.

Tačiau apskaičiuotieji koreliacinès matricos elementai rodo ne tik rodiklio, gauto išmatavus vertikaliuosius Žemès paviršiaus judesius, sq̨veiką su teritorijos geologiniais rodikliais, bet ir geologiniu rodikliu tarpusavio squveikas. Bet koks rodiklis teikia daugiau informacijos apie matavimo rezultato variacijas, jei jo koreliacijos su matavimo rodikliu koeficientas didesnis. Tačiau daugiau informacijos apie matavimais gautą rodiklį bendroje rodiklių sistemoje teiks tas rodiklis, kuris mažau koreliuoja su kitais rodiklių sistemos elementais. Rodiklių tarpusavio priklausomybe lemia tai, kad jie neteikia visos informacijos apie Žemès plutos judesius. Idealu būtų naudoti tokius rodiklius, kurie su išmatavus gautu rodikliu turètų stiprią koreliaciją, bet tarpusavyje būtų statistiškai 
nepriklausomi. Tačiau geologiniai rodikliai yra vientisos gamtinès sistemos elementai, todèl tarp jų visada yra priklausomybè ir idealus atvejis neimanomas. Todèl reikia ivertinti priklausomų rodiklių sistemu informatyvumą bei kompleksiškumą.

Nustatytieji ar išmatuotieji Žemès paviršiaus judesiai bei teritorijos geologiniai rodikliai (veiksniai) matematiniu statistiniu požiūriu sudaro vientisą kompleksą, todèl labiausiai nukrypstantiems nuo vientiso komplekso rodikliams nustatyti taikoma kompleksine koreliacinè analizè [3, 4].

Nagrinèjamu rodiklių grupès kompleksiškumo skaitmeninis rodiklis yra vidinès kompleksinès koreliacijos koeficientas

$$
R_{V}=\frac{2 \sum_{i \neq j}\left|r_{i j}\right|}{m(m-1)},
$$

čia $i$ - koreliacinès matricos eilutès numeris, $j$ - matricos stulpelio numeris, $m$ - kompleksą sudarančių rodiklių skaičius. Jeigu $R_{V} \geq 0,5$ - galima teigti, kad rodikliai sudaro statistiškai pagrịstą bendrą kompleksą.

Labiausiai nukrypstantiems nuo bendro komplekso rodikliams nustatyti skaičiuojami grupinès koreliacijos koeficientai:

$$
r_{j_{0}}=\frac{\sum_{i \neq j_{0}}\left|r_{j_{0} j}\right|}{m-1},
$$

čia $j_{o}$ - rodiklio, kurio grupinès koreliacijos koeficientas skaičiuojamas, numeris.

Atliekant analizę, rodiklis, kurio grupinès koreliacijos koeficientas mažiausias, eliminuojamas iš tolesnio tyrimo, nes galima teigti, jog jo statistiniai ryšiai su bendru kompleksu silpniausi. Taikant toki rodikliu eliminavimą, žingsniniu būdu galima sumažinti rodiklių skaičių, nemažinant arba nežymiai mažinant bendrajj informacijos kieki apie nagrinèjamą reiškini, t. y. mažesnès apimties rodiklių kompleksas gali pakankamai gerai atspindèti nagrinejjamą procesą.

Skirtingų rodiklių grupių informatyvumui ivertinti bei kompleksinès koreliacijos analizei [4] galime taikyti Helvingo (Hellwing) metodą [5\}. Rodiklių (požymiu) kombinacijoje $S k$-ojo požymio informatyvumas yra

$$
h_{k_{s}}=\frac{r_{0 k}^{2}}{1+\sum_{i \neq j, i \neq k}\left|r_{i k}\right|+\sum_{i \neq j, j \neq k}\left|r_{k j}\right|} \text {. }
$$

Visos požymių kombinacijos $S$ informatyvumas bus

$$
H_{S}=\sum_{k} h_{k_{s}} \text {. }
$$

Požymių kombinacijos informatyvumo rodiklis $H_{S}$ visuomet bus $0 \leq H_{S} \leq 1$. Kuo $H_{S}$ reikšmè artimesnè vienetui, tuo informatyvesnè tiriamoji požymių kombinacija. Tačiau rodiklis $H_{S}$ apibūdina ne absoliutų informacijos kieki, o informacijos kiekių santykius, esant ¿̇vairioms rodiklių kombinacijoms.

\section{Tyrimų rezultatai}

Remiantis aprašytaja metodika tyrimams atlikti pasirinkta pirmosios klasès niveliacijos linija Mikytai Klaipeda - Palanga. Čia matavimai atlikti 1936, 1954, 1963, 1975, 2003 metais. Matavimus atliko atitinkamai Krašto apsaugos ministerijos Karo topografijos skyrius, VGKV Maskvos aerogeodezinè imonè, Kauno politechnikos instituto Geodezijos katedra, Vilniaus inžinerinio statybos instituto Geodezijos katedra, VGTU Geodezijos institutas. Matavimų tikslumas apibūdinamas $\pm 0,18- \pm 0,5 \mathrm{~mm} / \mathrm{km}$ aukščiu skirtumu vidutine kvadratine paklaida. Apskaičiuoti Žemès paviršiaus judesių greičiai 1936-1963, 1936-1975, 1936-2003, 1954-1963, 1954-1975, 1954-2003, 1963-2003, 1975-2003 metu laikotarpiais bei viso laikotarpio nuo 1936 iki 2003 metų Žemès paviršiaus judesių greičių vidurkis.

Tiriamos teritorijos geologinę, geomorfologinę sandrą nusakantys rodikliai gauti iš Lietuvos geologijos tarnybos skaitmeninių duomenu bazès. Tai: nuosèdinès dangos storis, kaledoninio komplekso storis, hercyninio komplekso storis, apatinio silūro storis, alpinio komplekso storis, magnetinis laukas.

Geodezinių matavimu šioje trasoje duomenu ir geologinių teritorijos rodiklių koreliacijos su išmatuotais Žemès paviršiaus judesiais analizé atlikta [6], [7] darbuose, jų rezultatais pasinaudosime tolesniems tyrimams. Išmatuotų Žemès paviršiaus judesių greičių bei geologinių, geomorfologinių teritorijos rodikliu koreliacijos, nustatytos [7] darbe, pateiktos 1 lentelèje.

1 lentelè. Vertikaliujų Žemès paviršiaus judesių greičių koreliacija su geologiniais, geomorfologiniais rodikliais

Table 1. The correlation of vertical Earth surface movement speed with geological, geomorphologic parameter

\begin{tabular}{|c|c|c|c|c|c|c|}
\hline $\begin{array}{c}\text { Laiko- } \\
\text { tarpis, } \\
\text { metais }\end{array}$ & $r\left(x_{1} x_{2}\right)$ & $r\left(x_{1} x_{3}\right)$ & $r\left(x_{1} x_{4}\right)$ & $r\left(x_{1} x_{5}\right)$ & $r\left(x_{1} x_{6}\right)$ & $r\left(x_{1} x_{7}\right)$ \\
\hline $1936-1963$ & 0,64 & 0,64 & 0,55 & $-0,37$ & $-0,5$ & $-0,51$ \\
\hline $1936-1975$ & 0,52 & 0,31 & 0,54 & $-0,38$ & $-0,40$ & $-0,32$ \\
\hline $1936-2003$ & 0,65 & 0,58 & 0,92 & $-0,61$ & $-0,82$ & $-0,73$ \\
\hline $1954-1963$ & 0,56 & 0,51 & 0,69 & $-0,29$ & $-0,6$ & $-0,66$ \\
\hline $1954-1975$ & 0,57 & 0,4 & 0,7 & $-0,49$ & $-0,56$ & $-0,56$ \\
\hline $1954-2003$ & 0,74 & 0,72 & 0,89 & $-0,62$ & $-0,78$ & $-0,79$ \\
\hline $1963-2003$ & 0,7 & 0,66 & 0,84 & $-0,64$ & $-0,74$ & $-0,74$ \\
\hline $1975-2003$ & 0,55 & $-0,31$ & 0,88 & $-0,45$ & $-0,77$ & $-0,79$ \\
\hline $\begin{array}{c}\text { Viso } \\
\text { laikotarpio } \\
\text { vidurkis }\end{array}$ & 0,57 & 0,52 & 0,49 & $-0,43$ & $-0,42$ & $-0,39$ \\
\hline
\end{tabular}

Pastaba: $x_{1}-$ vertikaliujų Žemès paviršiaus judesių greičiai, $\mathrm{mm} / \mathrm{m}$., $x_{2}$ - nuosédinès dangos storis, $x_{3}-$ kaledoninio komplekso storis, $x_{4}-$ hercyninio komplekso storis, $x_{5}-$ apatinio silūro storis, $x_{6}-$ alpinio komplekso storis, $x_{7}-$ magnetinis laukas. 
Iš 1 lentelès matyti, kad stipriausieji Žemès paviršiaus judesių koreliaciniai ryšiai yra su hercyninio, alpinio kompleksų storiais, nuosėdinès dangos storiu, magnetiniu lauku $\left(0,40 \leq\left|r_{i j}\right| \leq 0,92\right)$. Kiek silpnesni - su kaledoninio komplekso bei apatinio silūro storiais $(0,29 \leq$ $\left.\left|r_{i j}\right| \leq 0,72\right)$. Skirtingų laikotarpių Žemès paviršiaus judesių koreliaciniai ryšiai su teritorijos geologiniais, geomorfologiniais rodikliais šiek tiek skirtingi.

Vidinès kompleksinès koreliacijos (2) ir grupinès koreliacijos (3) rodikliams nustatyti buvo apskaičiuota pilnoji koreliacinè matrica (1). Vidinès kompleksinès ir grupinès koreliacijos tyrimo rezultatai pateikti 2 lentelèje.

Iš 2 lentelejje pateiktų rezultatų matyti, jog labiausiai nuo bendro komplekso nutolęs rodiklis - kaledoninio komplekso storis. Pagal bendras tendencijas, jau tyrimo pradžioje eliminavus ši rodikli, gaunami pakankamai tvirti vidinès kompleksinès koreliacijos ryšiai tarp išmatuotų vertikaliujų Žemès paviršiaus judesių bei teritorijos geologinių, geomorfologinių charakteristikų. Norint gauti tvirčiausiais ryšiais susietą rodiklių kompleksą, toliau šalinami rodikliai, kurių grupinès koreliacijos koeficientai mažiausi. Tyrimų eigoje gaunama, jog didžiausias vidinès kompleksinès koreliacijos ryšys sieja $x_{1}, x_{4}, x_{6}$ bei $x_{7}$ rodiklių grupes $\left(0,69 \leq R \leq 0,8\right.$ ir $\left.0,42 \leq k_{j o} \leq 0,91\right)$. Šie rodikliai išlieka analizuojant visus kartotinių niveliacijų variantus. Šių keturių rodiklių ir vertikaliujų Žemès paviršiaus judesių greičių vidinès kompleksinès koreliacijos koeficientas (2) yra daug didesnis nei taikant visų požymių kompleksą. Tai reiškia, kad matavimų rezultatams interpretuoti geotektoniniu požiūriu ir prognostiniams modeliams sudaryti nebūtina naudoti daug rodiklių, tik svarbu tinkamai juos atrinkti.

2 lentelè. Vertikaliụjų Žemès paviršiaus judesių bei geologinių, geomorfologinių rodiklių grupinès ir vidinès kompleksinès koreliacijos koeficientai

Table 2. Vertical Earth surface movement and geological, geomorphologic factors, group and average complex correlation coefficients

\begin{tabular}{|c|c|c|c|c|c|c|c|c|}
\hline \multirow{3}{*}{$\begin{array}{l}\text { Laikotarpis, } \\
\text { metais }\end{array}$} & \multicolumn{7}{|c|}{ Grupinès koreliacijos koeficientai $k_{j 0}$} & \multirow{3}{*}{$\begin{array}{c}\text { Kompleksines koreliacijos } \\
\text { koeficientai } R_{V}\end{array}$} \\
\hline & \multicolumn{7}{|c|}{ Rodikliai } & \\
\hline & 1 & 2 & 3 & 4 & 5 & 6 & 7 & \\
\hline \multirow{4}{*}{$1936-1963$} & 0,54 & 0,43 & 0,41 & 0,53 & 0,48 & 0,51 & 0,52 & 0,49 \\
\hline & 0,51 & 0,34 & - & 0,60 & 047 & 0,60 & 0,60 & 0,52 \\
\hline & 0,48 & - & - & 0,70 & 0,41 & 0,74 & 0,73 & 0,61 \\
\hline & 0,52 & - & - & 0,82 & - & 0,82 & 0,82 & 0,75 \\
\hline \multirow{4}{*}{$1936-1975$} & 0,41 & 0,45 & 0,36 & 0,52 & 0,45 & 0,48 & 0,48 & 0,45 \\
\hline & 0,43 & 0,35 & - & 0,59 & 0,41 & 0,57 & 0,55 & 0,48 \\
\hline & 0,41 & - & - & 0,66 & 0,33 & 0,68 & 0,66 & 0,55 \\
\hline & 0,42 & - & - & 0,82 & - & 0,78 & 0,75 & 0,69 \\
\hline \multirow{4}{*}{ 1936-2003 } & 0,72 & 0,63 & 0,61 & 0,76 & 0,49 & 0,61 & 0,57 & 0,63 \\
\hline & 0,74 & 0,58 & 0,59 & 0,81 & - & 0,69 & 0,66 & 0,68 \\
\hline & 0,76 & - & 0,51 & 0,85 & - & 0,78 & 0,75 & 0,73 \\
\hline & 0,82 & - & - & 091 & - & 0,91 & 0,87 & 0,88 \\
\hline \multirow{4}{*}{ 1954-1963 } & 0,55 & 0,39 & 0,37 & 0,49 & 0,43 & 0,52 & 0,49 & 0,46 \\
\hline & 0,56 & 0,29 & - & 0,58 & 0,39 & 0,60 & 0,59 & 0,50 \\
\hline & 0,56 & - & - & 0,71 & 0,24 & 0,73 & 0,73 & 0,61 \\
\hline & 0,65 & - & - & 0,87 & - & 0,85 & 0,86 & 0,81 \\
\hline \multirow{4}{*}{ 1954-1975 } & 0,55 & 0,40 & 0,39 & 0,49 & 0,45 & 0,53 & 0,49 & 0,47 \\
\hline & 0,58 & 0,30 & - & 0,57 & 0,41 & 0,59 & 0,57 & 0,50 \\
\hline & 0,58 & - & - & 0,70 & 0,33 & 0,71 & 0,71 & 0,60 \\
\hline & 0,61 & - & - & 0,87 & - & 0,84 & 0,83 & 0,79 \\
\hline \multirow{4}{*}{ 1954-2003 } & 0,76 & 0,66 & 0,62 & 0,76 & 0,52 & 0,60 & 0,62 & 0,65 \\
\hline & 0,78 & 0,62 & 0,61 & 0,79 & - & 0,68 & 0,70 & 0,70 \\
\hline & 0,80 & 0,55 & - & 0,84 & - & 0,76 & 0,76 & 0,74 \\
\hline & 0,82 & - & - & 0,90 & - & 0,89 & 0,88 & 0,87 \\
\hline \multirow{4}{*}{ 1963-2003 } & 0,72 & 0,68 & 0,64 & 0,77 & 0,57 & 0,62 & 0,65 & 0,66 \\
\hline & 0,73 & 0,64 & 0,63 & 0,80 & - & 0,69 & 0,72 & 0,70 \\
\hline & 0,76 & 0,57 & - & 0,84 & - & 0,76 & 0,77 & 0,74 \\
\hline & 0,77 & - & - & 0,89 & - & 0,87 & 0,87 & 0,85 \\
\hline \multirow{4}{*}{ 1975-2003 } & 0,63 & 0,47 & 0,36 & 0,55 & 0,40 & 0,49 & 0,48 & 0,48 \\
\hline & 0,69 & 0,38 & - & 0,66 & 0,33 & 0,56 & 0,57 & 0,53 \\
\hline & 0,75 & 0,26 & - & 0,77 & - & 0,68 & 0,71 & 0,63 \\
\hline & 0,81 & - & - & 0,69 & - & 0,90 & 0,90 & 0,88 \\
\hline \multirow{4}{*}{$\begin{array}{c}\text { Viso } \\
\text { laikotarpio } \\
\text { vidurkis }\end{array}$} & 0,47 & 0,42 & 0,39 & 0,52 & 0,49 & 0,50 & 0,50 & 0,47 \\
\hline & 0,46 & 0,32 & - & 0,59 & 0,48 & 0,58 & 0,57 & 0,50 \\
\hline & 0,43 & - & - & 0,68 & 0,42 & 0,72 & 0,70 & 0,59 \\
\hline & 0,43 & - & - & 0,80 & - & 0,78 & 0,78 & 0,70 \\
\hline
\end{tabular}


Remiantis gautais rezultatais galima teigti, jog didžiausios itakos grupinei koreliacijai turi hercyninio, alpinio kompleksu storiai bei magnetinis laukas. Koreliaciniai ryšiai tarp išmatuotų Žemès paviršiaus judesių bei teritorijos geologiniu, geomorfologiniu charakteristiku byloja, jog atlikus geodezinius matavimus nustatyti Žemès plutos judesiai nèra reperių nepastovumo bei atsitiktinio pobūdžio paklaidų rezultatas, nes tiriant buvo pastebėtas objektyviai egzistuojantis dèsningas gamtinis reiškinys.

Skirtingu rodiklių grupių informatyvumo tyrimo rezultatai, gauti pagal siūlomą metodiką, pateikti 3 lentelèje.

Atsižvelgiant i kompleksinès koreliacinès analizès rezultatus (2 lentelè), rodiklių informatyvumo tyrimams sudarytos keturios požymių kombinacijos. I pirmajją požymių kombinaciją jeina visi geologiniai, geomorfologiniai rodikliai, naudoti atliekant minètuosius tyrimus. Kaip matome iš pateiktu tyrimu rezultatų (3 lentelè), informatyviausias hercyninio komplekso storis, mažiausiai informatyvus - apatinio silūro storis. Visos atitinkamais laikotarpiais išmatuotų Žemès plutos judesių rodikliu grupès gana informatyvios, išskyrus, kaip jau minèta, nebent apatinio silūro storị. Tačiau iš antroje lentelèje pateiktų tyrimo, atlikto taikant kompleksinę koreliacinę analizę, duomenų matyti, jog tam tikros rodiklių grupès nesudaro bendro komplekso su išmatuotais Žemès plutos judesiais, tad atliekant tyrimą tèra pašaliniai trukdžiai. Todèl antrajai požymių kombinacijai priskirti rodikliai, kurių grupinès korelia- cijos koeficientai yra didžiausi (hercyninio komplekso bei alpinio komplekso storiai, magnetinis laukas) (2 lentelè). Požymių kombinacijos informatyvumas šiek tiek sumažèja, nes iš tyrimo rezultatú eliminuoti tam tikri rodikliai. Tačiau kadangi jie nesudaro bendro komplekso su išmatuotais Žemès paviršiaus judesiais, tyrimui teikia nemažai pašalinès informacijos.

Trečiajai rodiklių kombinacijai rodikliai parinkti šiuo būdu: išanalizavus trečiosios požymių kombinacijos rezultatus, atmesta mažiausiai informatyvi rodiklių grupè. Kaip matome, informatyviausi rodikliai - hercyninio komplekso storis bei magnetinis laukas. Taikant šią rodiklių kombinaciją, gaunamas didesnis ịvairių požymių bei visos požymių kombinacijos informatyvumas.

Ketvirtajai kombinacijai atrinkti tie rodikliai, kurie, atlikus kompleksinę koreliacinę analizę (2 lentelè), buvo eliminuoti kaip turintys neigiamos itakos grupinès koreliacijos koeficientui (nuoseddinès dangos, kaledoninio komplekso, apatinio silūro storiai). Kaip matome, šios rodiklių grupès šiek tiek informatyvios, tačiau kadangi šie rodikliai nesudaro bendro komplekso (2 lentelè), ju informatyvumas apie tiriamaji reiškini yra šalutinio, nepageidautino pobūdžio.

Iš 3 lentelëje pateiktu tam tikrų rodikliu grupių informatyvumo analizès rezultatų galima teigti, jog visi geologiniai rodikliai ir visos rodiklių grupès teikia nemažai informacijos, susijusios su geodeziniais metodais nustatytais dabartiniais Žemès plutos judesiais.

3 lentelè. Geologinių rodiklių lyginamasis informatyvumo įvertinimas atlikus kartotines niveliacijas Lietuvos pajūryje

Table 3. The comparative informative rating of geological factors accounting to reversed Lithuania seaside leveling

\begin{tabular}{|c|c|c|c|c|c|c|c|c|c|}
\hline \multirow[b]{2}{*}{$\begin{array}{c}\text { Geologiniai } \\
\text { rodikliai }\end{array}$} & \multicolumn{9}{|c|}{ Vertikalieji Žemės plutos judesiai įvairiais laikotarpiais } \\
\hline & $\begin{array}{c}1936- \\
1975\end{array}$ & $\begin{array}{c}1954- \\
1963\end{array}$ & $\begin{array}{c}1936- \\
1963\end{array}$ & $\begin{array}{c}1975- \\
2003\end{array}$ & $\begin{array}{c}1963- \\
2003\end{array}$ & $\begin{array}{c}1954- \\
2003\end{array}$ & $\begin{array}{c}1954- \\
1975\end{array}$ & $\begin{array}{c}1936- \\
2003\end{array}$ & $\begin{array}{c}\text { Viso } \\
\text { laikotarpio } \\
\text { vidurkis }\end{array}$ \\
\hline \multicolumn{10}{|c|}{ Pirmoji požymių kombinacija } \\
\hline$x_{2}$ & 0,085 & 0,113 & 0,139 & 0,092 & 0,112 & 0,130 & 0,115 & 0,103 & 0,110 \\
\hline$x_{3}$ & 0,034 & 0,097 & 0,144 & 0,036 & 0,105 & $0,0,130$ & 0,055 & 0,083 & 0,095 \\
\hline$x_{4}$ & 0,082 & 0,148 & 0,083 & 0,226 & 0,148 & 0,171 & 0,151 & 0,182 & 0,066 \\
\hline$x_{5}$ & 0,044 & 0026 & 0,039 & 0,069 & 0,109 & 0,110 & 0,075 & 0,112 & 0,052 \\
\hline$x_{6}$ & 0,046 & 0,102 & 0,070 & 0,187 & 0,137 & 0,159 & 0,087 & 0,177 & 0,050 \\
\hline$x_{7}$ & 0,029 & 0,133 & 0,073 & 0,204 & 0,132 & 0,159 & 0,094 & 0,145 & 0,042 \\
\hline$H_{1}$ & 0,320 & 0,619 & 0,548 & 0,814 & 0,743 & 0,859 & 0,577 & 0,802 & 0,415 \\
\hline \multicolumn{10}{|c|}{ Antroji požymių kombinacija } \\
\hline$x_{4}$ & 0,100 & 0,163 & 0,104 & 0,269 & 0,250 & 0,283 & 0,168 & 0,301 & 0,082 \\
\hline$x_{6}$ & 0,054 & 0,122 & 0,084 & 0,203 & 0,190 & 0,211 & 0,106 & 0,231 & 0,060 \\
\hline$x_{7}$ & 0,035 & 0,149 & 0,088 & 0,215 & 0,191 & 0,220 & 0,107 & 0,185 & 0,052 \\
\hline$H_{l}$ & 0,189 & 0,434 & 0,276 & 0,687 & 0,631 & 0,714 & 0,381 & 0,717 & 0,194 \\
\hline \multicolumn{10}{|c|}{ Trečioji požymių kombinacija } \\
\hline$x_{4}$ & 0,150 & 0,244 & 0,155 & 0,401 & 0,371 & 0,421 & 0,251 & 0,448 & 0,123 \\
\hline$x_{7}$ & 0,053 & 0,223 & 0,133 & 0,323 & 0,288 & 0,332 & 0,161 & 0,282 & 0,078 \\
\hline$H_{1}$ & 0,203 & 0,467 & 0,288 & 0,724 & 0,659 & 0,753 & 0,412 & 0,730 & 0,201 \\
\hline \multicolumn{10}{|c|}{ Ketvirtoji požymių kombinacija } \\
\hline$x_{2}$ & 0,102 & 0,120 & 0,156 & 0,108 & 0,174 & 0,196 & 0,124 & 0,150 & 0,124 \\
\hline$x_{3}$ & 0,037 & 0,102 & 0,166 & 0,039 & 0,168 & 0,203 & 0,062 & 0,129 & 0,109 \\
\hline$x_{5}$ & 0,061 & 0,036 & 0,060 & 0,077 & 0,161 & 0,154 & 0,101 & 0,146 & 0,081 \\
\hline$H_{1}$ & 0,200 & 0,258 & 0,382 & 0,224 & 0,503 & 0,553 & 0,287 & 0,425 & 0,314 \\
\hline
\end{tabular}


Tačiau dèl to, kad rodikliai susieti koreliacinèmis priklausomybèmis ne tik su Žemès plutos judesiais, bet ir tarpusavyje, sudarant prognostinius dabartiniu Žemès plutos judesių modelius, visų rodiklių jungti i vieną sistemą netikslinga. Reikia naudoti tokias rodiklių grupes, kurios tarpusavyje sudaro tvirtus statistinius kompleksus. Taip galima sumažinti prognozėms ir matavimų rezultatams geotektoniniu požiūriu interpretuoti naudojamu rodiklių skaičiuc, nesumažinant galutinio rezultatų tikslumo ar net padidinant ji. Rezultatų kontrolei galima naudoti pavienes informatyvumo požiūriu bendrus kompleksus sudarančias rodiklių grupes.

\section{Išvados}

1. Lietuvos pajūryje išmatuoti dabartiniai vertikalieji Žemès plutos judesiai statistiniais ryšiais susieti su teritorijos geologiniais rodikliais. Todèl galima teigti, kad dabartiniai Žemès plutos judesiai šioje teritorijoje yra ankstesnių tektoninių judesiu tąsa, ir ju prognozei galima naudoti teritorijos geologinius rodiklius.

2. Daugiausia informacijos apie išmatuotų Žemès paviršiaus judesių sąsajas su tektoninès kilmès Žemès plutos judesiais teikia hercyninio ir alpinio komplekso nuosėdinès dangos sluoksniai bei Žemès magnetinis laukas.

3. Kadangi teritorijos geologiniai rodikliai yra tarpusavyje statistiškai susieti, ne visada didesnis rodikliu kiekis teikia daugiau informacijos apie išmatuotų Žemès plutos judesių tektoninę prigimtị. Todèl, norint panaudoti geologinius rodiklius išmatuotų dydžių geotektoniniam interpretavimui, prognozei bei dabartinių tektoninių procesu kinematiniams modeliams sudaryti teritorijose, kurios stora nuosédinè danga, reikia atlikti rodikliu informatyvumo analizę ir parinkti informatyviausių rodikliu grupes.

\section{Literatūra}

1. Geology of Lithuania (ed. A. Grigelis, V. Kadūnas). Vilnius: Publishing house of encyclopedias and sciences, 1994. 447 p. (in Lithuanian).

2. Tectonic Structure of Lithuania (ed. P. Suveizdis). Vilnius: Institute of geology and geography, 2003. 160 p. (in Lithuanian).

3. Zakarevičius, A. Investigation of the Recent Geodynamic Processes in the Territory of Lithuania (Dabartiniu geodinaminiu procesu Lietuvos teritorijoje tyrimas). Vilnius: Technika, 2003. 195 p. (in Lithuanian).

4. Zakarevičius, A. The Intercomponental Correlative Analysis of the Maps of the Vertical Earth's Crust Movements within in Balticum Territory. Papers of Geodesy, No XI. Vilnius: Vilniaus inžinerinis statybos institutas, 1982, p. 57-64.

5. Hellwig, Z. Problem optymalnego wyboru predyktant. Przeglad statystyczny, 1969, No 3-4, p. 221-237 (in Polish).

6. Puziene, R.; Zakarevicius, A. Interrelation Between Changes of Heights of Signs on a Vertical Geodetic Network and Tectonic Structures At The Baltic Coast. In:
Proceedings of the International Scientific Methodical Conference „Land use and land management“, Tartu, 2004, p. 66-68 (in Russian).

7. Zakarevicius, A.; Sliaupa, S.; Puziene, R.; Anikeniene, A.; Buga, A.; Denas. Z. Tectonic Interpretation of Measured Recent Movements of the Earth Surface of Sedimentary Basin. In: Selected papers of $6^{\text {th }}$ International Conference „Environmental Engineering“, Vol 2, Vilnius: Technika, 2005, p. 1034-1040.

Algimantas ZAKAREVIČIUS. Doctor Habil, Professor. Dept of Geodesy and Cadastre, Vilnius Gediminas Technical University, Sauletekio al. 11, LT-10223 Vilnius-40, Lithuania $(\mathrm{Ph}+37052744701)$,

e-mail: Algimantas.Zakarevicius@ap.vtu.lt.

A graduate of Kaunas Polytechnic Institute (now Kaunas University of Technology), geodetic engineer, 1965. Doctor's degree at Vilnius University, 1973. Dr Habil degree at VGTU, 2000. Member of the Geodetic Commission of Estonia, Latvia and Lithuania. Research training at Geodetic Institute of Norwegian Mapping Authority, 1994. Author of over 130 publications and 3 monographs.

Research interests: investigations of the recent geodynamic processes, formation of geodetic networks.

Rūta PUZIENE். Doctoral student. Vilnius Gediminas Technical University, Dept of Geodesy and Cadastre, Sauletekio al. 11, LT-10223 Vilnius, Lithuania $(\mathrm{Ph}$ +37052744703), e-mail: rutapu@ delfi.lt.

A graduate of Vilnius Gediminas Technical University (Master of science, 2003). Co-author of 2 publications.

Research interests: investigation of geodynamic processes, investigations of deformations. 